\title{
Identification of side population cells in mouse primordial germ cells and prenatal testis
}

\author{
MARIA-LUCIA SCALDAFERRI ${ }^{1}$, STEFANIA FERA², LAURA GRISANTI'2, MASSIMO SANCHEZ³, \\ MARIO STEFANINI ${ }^{2}$, MASSIMO DE FELICI ${ }^{1}$ and ELENA VICINI*,2 \\ ${ }^{1}$ Department of Public Health and Cell Biology, University of Rome Tor Vergata, ${ }^{2}$ Fondazione Pasteur Cenci \\ Bolognetti, Department of Histology and Medical Embryology "La Sapienza" University of Rome and \\ ${ }^{3}$ Department of Cell Biology and Neuroscience, Istituto Superiore di Sanità, Rome, Italy
}

\begin{abstract}
In mammals, the stem cells of spermatogenesis are derived from an embryonic cell population called primordial germ cells (PGCs). Spermatogonial stem cells displaying the "side population" (SP) phenotype have been identified in the immature and adult mouse testis, but noting is known about the expression of the SP phenotype during prenatal development of germ cells. The SP phenotype, defined as the ability of cells to efflux fluorescent dyes such as Hoechst, is common to several stem/progenitor cell types. In the present study, we analyzed and characterized the Hoechst SP via cytofluorimetric analysis of disaggregated gonads at different time points during embryonic development in mice. To directly test the hypothesis that the SP phenotype is a feature of germ cell lineage, experiments were performed on transgenic animals expressing enhanced green fluorescent protein (EGFP) under the control of the Oct4 promoter, to identify early germ cells up to PGCs. We found that prenatal gonads contain a fraction of SP cells at each stage analyzed, and the percentage of cells in the SP fraction decreases as development proceeds. Surprisingly, more than $50 \%$ of the PGCs displayed the SP phenotype at 11.5 dpc (days post coitum). The percentage of germ cells with the SP phenotype decreased steadily with development, to less than $1 \%$ at 18.5 dpc. Cytofluorimetric analysis along with immunocytochemistry performed on sorted cells indicated that the SP fraction of prenatal gonads, as in the adult testis, was heterogeneous, being composed of both somatic and germ cells. Both cell types expressed the ABC transporters Abcg2, Abcb1a, Abcb1b and Abcc1. These findings provide evidence that the SP phenotype is a common feature of PGCs and identifies a subpopulation of fetal testis cells including prospermatogonia whose differentiation fate remains to be investigated.
\end{abstract}

KEY WORDS: testis development, spermatogonial stem cell, side population, Oct4-GFP

In adult mammals, continuous production of spermatozoa is sustained by spermatogonial stem cells (SSCs). SSCs are derived from a population of embryonic precursors called primordial germ cells (PGCs). In the mouse embryo, the progenitors of PGCs appear as Blimp-1 positive cells in the epiblast as early as 6.25 days post coitum (dpc) (Ohinata et al., 2005). At about 7.5 dpc, 30-40 PGCs are specified in the extraembryonic mesoderm, in the root of the developing allantois posterior to the primitive streak (Ginsburg et al., 1990; Lawson and Hage, 1994). As embryonic development proceeds, PGCs actively migrate to reach and enter the developing gonads. At $11.5 \mathrm{dpc}$, all PGCs have reached the future gonads and compose a population of around 3000 cells. Around 13.5 dpc, PGCs differentiate according to the genetic sex of the embryo; in females, they differentiate into meiotic oocytes, entering the prophase of meiosis I, whereas in males, they became G0-arrested prospermatogonia (De Felici and McLaren, 1983; Western et al., 2008). A few days after birth, germ cells resume proliferation and migrate to the basement membrane of the seminiferous tubules (Hilscher et al., 1974; McLaren, 1995). Most of the germ cells will further differentiate during the first wave of spermatogenesis to give rise to mature sperm, while few will become SSCs. A dramatic increase in number of stem cells takes place in the second week of postnatal life, after which time the final size of the stem cell compartment is

\footnotetext{
Abbreviations used in this paper: GR, gonadal ridge; Ho, Hoechst 33342; PGC, primordial germ cell; SP, side population; SSC spermatogonial stem cell.
}

*Address correspondence to: Elena Vicini. Via Antonio Scarpa 14, 00161 Roma, Italy. Fax: +39-06-4462-854. e-mail: elena.vicini@uniroma1.it 


\section{$11.5 \mathrm{dpc}$}
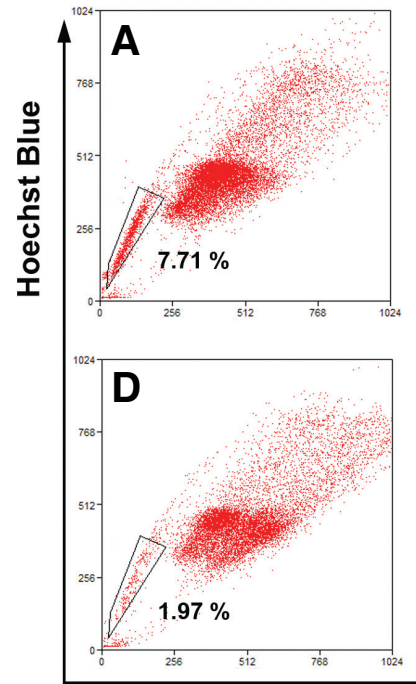

$13.5 \mathrm{dpc}$
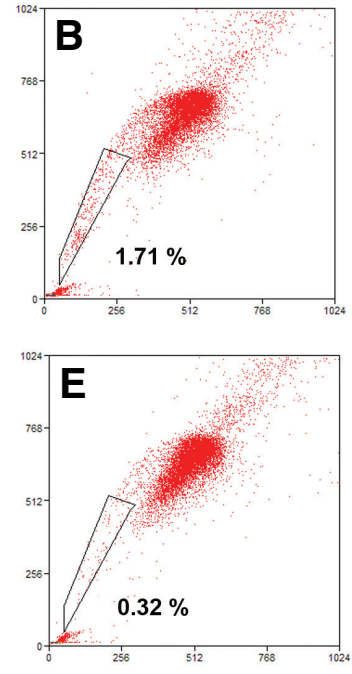

$18.5 \mathrm{dpc}$
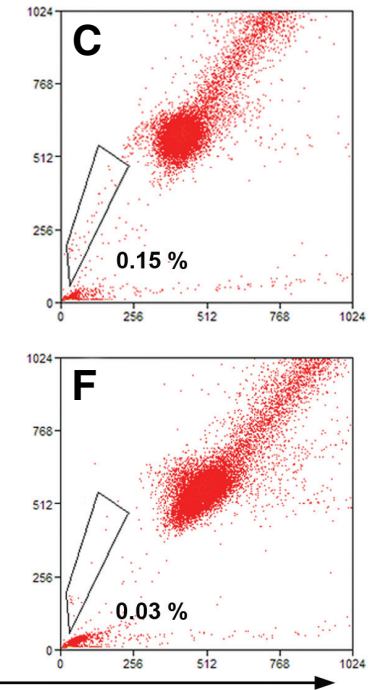

Hoechst Red
Fig. 1 (Above). In the embryonic mice testis, a subset of cells displays a side population (SP) phenotype. FACS profiles of wild-type embryonic testis cells stained with $\mathrm{Ho}(\mathbf{A}, \mathbf{B}, \mathbf{C})$ or with Ho in the presence of verapamil (D,E,F). Percentages of cells in the boxed SP regions are indicated. The presence of verapamil during the supravital Ho staining reduced SP fractions. A representative experiment is shown $(n=3)$.

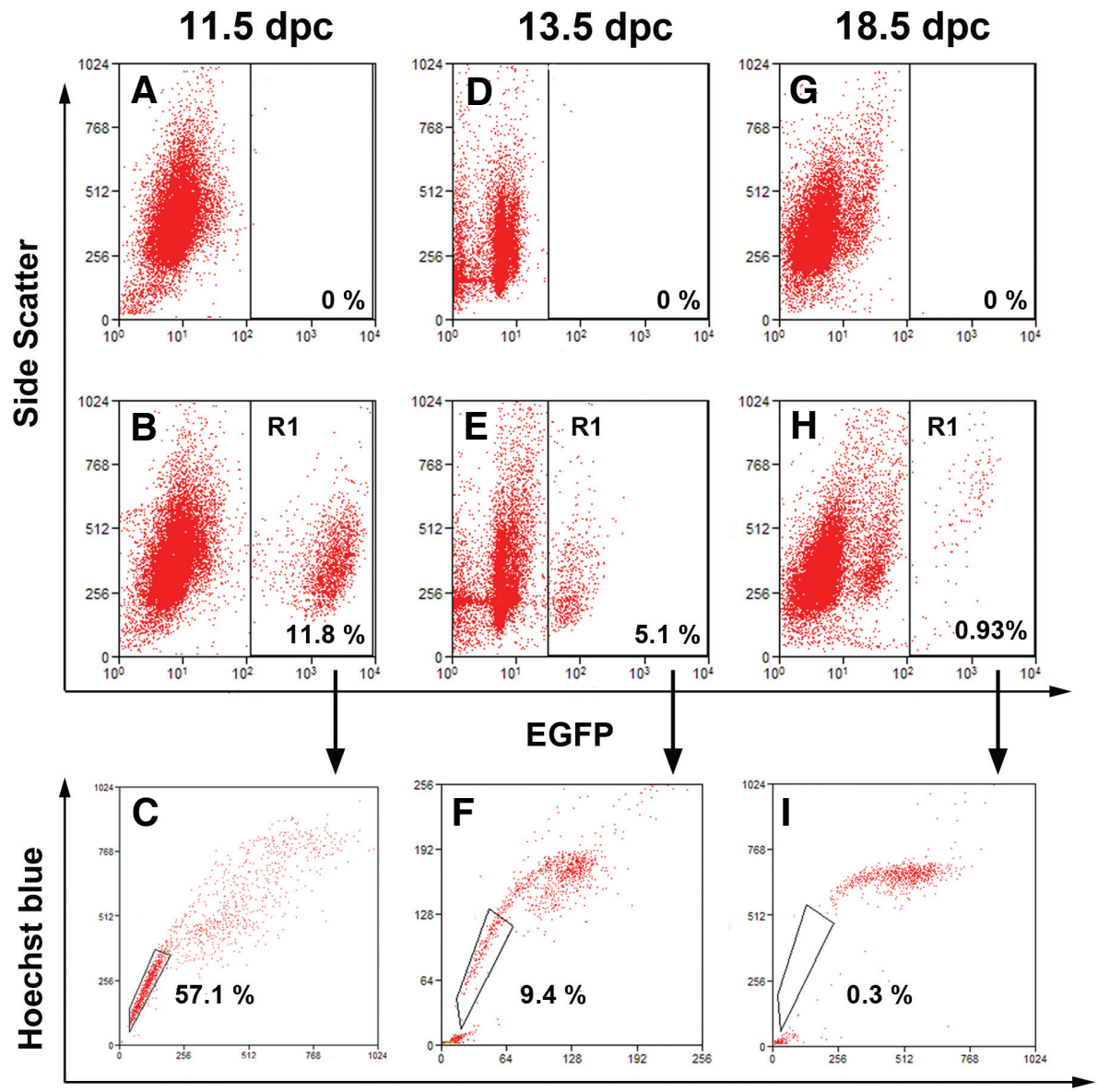

Hoechst red set (McLean et al., 2003). It has been recently suggested that adult SSCs are already selected among PGCs before 13.5 dpc (Ueno et al., 2009), but the molecular mechanisms underlying SSC fate commitment remain obscure.

Previous studies in the mouse have shown that SSCs can be identified by their ability to efflux dyes such as Hoechst 33342 (Falciatori et al., 2004; Lassalle et al., 2004). This ability, defined as the "side-population" (SP) phenotype, is common to several stem/progenitor cell types (Challen and Little, 2006) and relies on the activity of ATP-binding cassette (ABC) transporter superfamily, including multidrug resistance 1 (Mdr1a/1b, mouse; MDR1, human) and breast cancer resistance protein 1 (Bcrp1, mouse; ABCG2 human) (Bunting et al., 2000; Zhou et al., 2001). The activity of these transporters can be blocked by several inhibitors (verapamil, reserpin, Ko 123, and others). Inclusion of these inhibitors during dye incubation results in loss of the SP fraction. Although the precise function of the SP phenotype in stem cell physiology remains to be elucidated, it has proven valuable as a marker for identification of multipotent stem cells from a variety of tissues. SSCs displaying the SP phenotype have been identified in the immature and adult mouse testis (Falciatori et al., 2004, Lassalle et al., 2004) but no data have been available on SP expression in the prenatal testis to date. To investigate whether the SP phenotype is expressed earlier during testis development, we analyzed and characterized Hoechst staining via cytofluorimetric analysis of disaggregated gonads at different time points of prenatal development, up to sex-indifferent gonadal ridges. To directly test the hypothesis that SP phenotype is a feature of germ cell lineage, cytofluorimetric analyses were performed on transgenic animals expressing

Fig. 2. A subset of primordial germ cells displays an SP phenotype in the embryonic mice testis. FACS profile of cells stained with $\mathrm{HO}_{\mathrm{O}}$ isolated from wild-type embryonic testes (A,D,G) and age-matched Oct4-GFP embryonic testes $(\mathbf{B}, \mathbf{C}, \mathbf{E}, \mathbf{F}, \mathbf{H}, \mathbf{I})$. Wild-type testes were included in the analysis as negative controls to set gates for EGPF fluorescence. The fraction of EGFP-positive cells (germ cells) is indicated as $R 1$ at each age analyzed (B,E,H). Only a subset of germ cells fell in the SP region (C,F,I). The percentage of SP cells in the EGFP-expressing population is indicated for each age. A representative experiment is shown $(n=3)$. 
EGFP under the control of the Oct4 promoter, in order to identify male germ cells up to PGCs.

\section{Results}

To determine whether the SP phenotype is expressed in early testis development, we searched for SP cells in the gonads of the developing mouse embryo. Cells were disaggregated from 11.5 dpc gonadal ridges (GRs) and 13.5 and 18.5 dpc testes and subjected to Hoechst 33342 ( $\mathrm{Ho}$ ) vital staining using a protocol for detection of SP in immature testis (Falciatori et al., 2004). A small Ho-effluxing SP fraction was readily identified by cytometric analysis at all stages analyzed (Fig. $1 \mathrm{~A}, \mathrm{~B}, \mathrm{C})$. The percentage of cells in the SP fraction was highest in $11.5 \mathrm{dpc}$ GRs (mean \pm SEM, $8.15 \pm 0.26)$, when gonads are at sex indifferent stage, and decreased thereafter in 13.5 and $18.5 \mathrm{dpc}$ testes (1.44 \pm 0.07 and $0.11 \pm 0.02$, respectively). To assess whether Ho efflux could be blocked by inhibiting $A B C$ transporter activity, cells were stained with Ho in the presence of $50 \mu \mathrm{m}$ of verapamil. Cytofluorimetric analysis showed that, under these conditions, the SP fraction was markedly reduced at all stages (Fig. 1 D,E,F).

In several tissues and organs the SP fraction is heterogeneous in terms of cell types. In order to identify germ cells in the SP fraction, we took advantage of a transgenic mice model expressing EGFP under the control of the Oct4 promoter. Because Oct4 is expressed exclusively in the germline in the postimplantation mouse embryo (Yeom et al., 1996), this animal model has been widely used to identify and analyze germ cells during embryonic development (Anderson et al., 1999; Yoshimizu et al., 1999). Disaggregated cells from age-matched wild-type and transgenic gonads were vital stained with Ho and analyzed for both Ho and EGFP fluorescence levels (Fig. 2). Cytofluorimetric analyses of wild-type gonads were performed as a control to set gates for EGFP fluorescence (Fig. 2 A, D and G). In the GRs of the transgenic mice, around $10 \%$ of total cells were EGFPpos. FACS analysis showed that virtually all EGFPpos cells were positive for TG-1 (SSEA-1) antigen confirming their PGC identity (not shown). The percentage of EGFPpos cells dropped to $5 \%$ at 13.5 dpc and to less than $1 \%$ in 18.5-dpc testes (Fig. 2 B, $E$ and $H$ ). Since during this period nearly all male germ cells express the Oct4-EGFP transgene (Ohbo et al., 2003; Yoshimizu et al., 1999), we assume that such a decrease was due to the expansion of the testicular somatic cells in comparison to germ cells, which undergo G0 arrest around $13.5 \mathrm{dpc}$ (Western et al., 2008). To assess the percentage of germ cells displaying the SP phenotype at each stage, we analyzed the Ho profile of EGFPpos cells. Surprisingly, around $60 \%$ of EGFP pos cells displayed the SP phenotype at $11.5 \mathrm{dpc}$. The percentage of EGFPpos germ cells with the SP phenotype then steadily decreased with age, reaching less than $1 \%$ at 18.5 dpc (Fig. 2 C, F and I). Cytofluorimetric analysis indicated that EGFPpos represented more than $90 \%$ of total SP cells at $11.5 \mathrm{dpc}$, less than $15 \%$ at $13.5 \mathrm{dpc}$, and it became undetectable at $18.5 \mathrm{dpc}$ (not shown) suggesting that SP fraction in fetal testes is heterogeneous in terms of cell types. To further characterize the SP fraction, SP and non-SP cells were sorted from $13.5 \mathrm{dpc}$ testis and analyzed for the expression of VASA, a specific marker of germ cells (Tanaka et al., 2000) (Fig. 3A). As expected, we found that VASA-positive cells represented a fraction of total SP cells approximately in the range of the EGFPpos cells (see above) (Fig. 3B). These data indicate that, while a large percentage of PGCs express the SP phenotype in sex-indifferent GRs, this marker is restricted to a small prospermatogonia subpopulation and to unidentified gonadal somatic cell type/s by 13,5 dpc.

Finally, we used RT-PCR to identify which ABC transporter/s

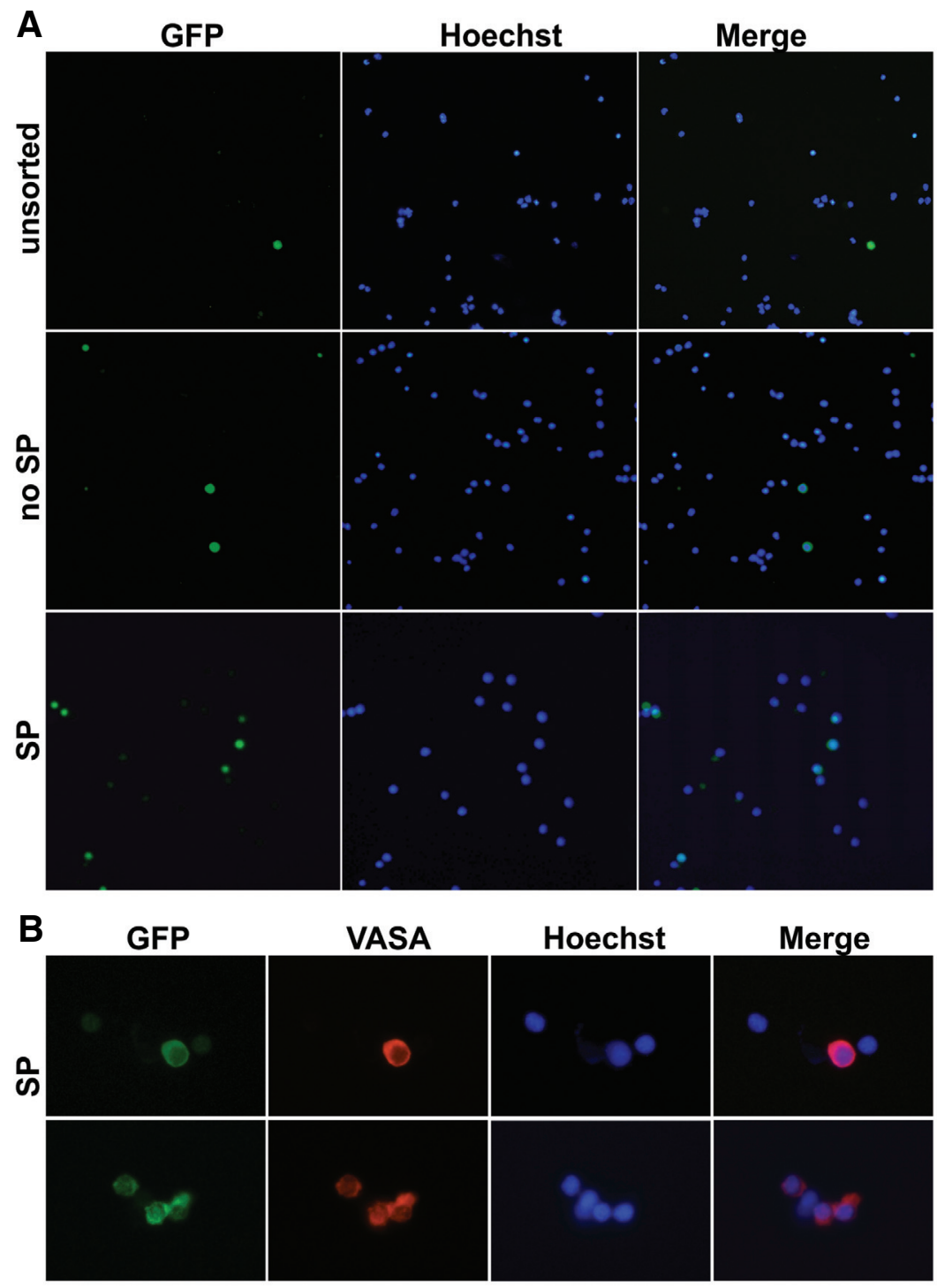

Fig. 3. Immunofluorescence for the germ cell specific VASA protein on Oct4EGFP cells isolated from 13.5 dpc testes of CD-1 x OG2-F1 mice. (A) Oct4-EGFPoos cells in unsorted cells, sorted no SP and sorted SP cells. (B) Immunofluorescence for VASA protein on SP cells. Pictures were acquired with an Zeiss Axyoplan II fluorescence microscope using a 20X (A) or a 60X (B) objectives. 


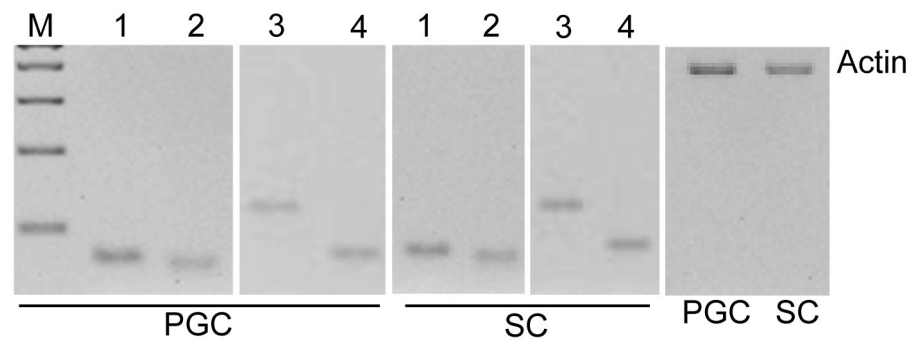

Fig.4. Representative RT-PCR analysis of ABC transporter gene expression in primordial germ cells (PGC) and somatic cells (SC) purified from $\mathbf{1 1 . 5}$ dpc gonadal ridges. Lanes represent: (1) Abcg2; (2) Abcb1a; (3) Abcb1b; (4) Abcc1. Actin is shown as loading control.

involved in Ho efflux are expressed in isolated PGCs and somatic cells. GRs at $11.5 \mathrm{dpc}$ were disaggregated, and PGCs and somatic cells were purified for RNA extraction (Pesce and De Felici, 1995). Semi-quantitative-PCR was then performed to analyze $A b c g 2$ (encoding for BCRP1), Abcb1a (encoding for MDR1a), $A b c b 1 b$ (encoding MDR1b), and $A b c c 1$ (encoding for MRP1) transcripts (Fig. 4). All transcripts analyzed were expressed in both PGCs and somatic cells.

\section{Discussion}

In the present study, we carried out an analysis of SP phenotype expression during prenatal development of the testis, up to the sex indifferent gonadal ridge stage. Using cytofluorimetry of Hoechst-stained gonadal cells, we found that, at $11.5 \mathrm{dpc}$, the embryonic stage at which gonads are still sex indifferent, the SP fraction represents a larger percentage of total viable cells (around $8 \%$ ) when compared to the percentage of SP cells in the postnatal testis (range 0.1-1.3\%(Falciatori et al., 2004). The number of cells in the SP fraction strongly decreased with time over the course of development, and by $18.5 \mathrm{dpc}$, the percentage of SP cells was equal to that of postnatal testes (Falciatori et al., 2004). By using transgenic mice in which the prenatal germ cells express EGFP, we also found that a large proportion of $11.5 \mathrm{dpc}$ PGCs (around $60 \%$ ) expressed the SP phenotype; at $18.5 \mathrm{dpc}$, however, less than $1 \%$ of EGFP pos prospermatogonia were found within the SP gate. Between 11.5 and $13.5 \mathrm{dpc}$, the percentage of the EGFPpositive cells in the gonads decreased from $12 \%$ to $5 \%$ (about a 2 -fold reduction) while, in the same time frame, the percentage of EGFP-positive cells in the SP gate decreased from about $60 \%$ to $10 \%$ (a 6 -fold reduction). This indicates that the decrease in the percentage of SP cells in the testis is not only due to the high proliferation rate of non-SP somatic and germ cells (Schmahl et al., 2000), but also to down-regulation of the SP phenotype in the male germ cell population.

Since the percentage of SP cells in a variety of cell populations is very low, usually less than $1 \%$ (Rochon et al., 2006; Zhou et al., 2001) the high percentage of PGCs displaying SP phenotype is somewhat surprisingly. Even in ES cells, which have a number of similarities with PGCs, the proportion of SP cells is below 5\% (Vieyra et al., 2009). Considering the lack of information about the physiological function of $A B C$ transporters in PGCs, we can only speculate regarding the reason for the high percentage of SP cells within the PGC population. Analogous to their possible functions in the stem/progenitor cells of adult tissues (Zhou et al., 2002), the activity of the $A B C$ transporters in $P G C s$ might provide protection from toxic substrates. Interestingly, ABCG2 activity prevents the accumulation of porphyrin, a constituent of heme, and ROSinduced DNA damage in ES cells. Moreover, inhibition of ABCG2 results in down-regulation of Nanog and Oct4 and therefore can impact the self-renewal of ES cells (Susanto et al., 2008). Although PGCs are germ line-committed cells under certain in vivo and in vitro conditions, they can actually transform into embryonal carcinoma (EC) and embryonal germ (EG) stem cell lines (De Felici et al., 2009; Donovan and De Miguel, 2003). Therefore, among the stemness characteristics usually associated with possible SP functions, differentiation and pluripotency could also be modulated by $A B C$ transporters in PGCs.

Taking into account the percentage of the SP cells in the whole gonad and the relative contribution of the EGFPpos germ cells to this fraction, it is evident that this subpopulation is composed of both germ and somatic cells. Detection of VASA-positive germ cells and VASA-negative somatic cells in sorted SP cells from $13.5 \mathrm{dpc}$ gonads further confirmed these findings. Consistently, our data indicated that both germ and somatic cells express all the $A B C$ transporters analyzed, particularly ABGC2, a molecular determinant of the Hoechst SP phenotype (Zhou et al., 2001). A previous study indicated that, in the adult testis, the SP fraction also contains stem/progenitors for androgen-producing Leydig cells in addition to SSCs (Lo et al., 2004). It would be interesting to test whether embryonic Leydig progenitor cells are also present in the SP fraction from prenatal testes.

Ohumura and colleagues recently showed that a nucleolar protein called nucleostemin, found at high levels in several types of stem cells, identifies germ cells with undifferentiated status and long-term testis repopulating capability in prenatal gonads (Ohmura et al., 2008). Interestingly, the expression pattern of this protein closely resembles that of the SP phenotype described here. Since SP phenotype is expressed by immature (Falciatori et al., 2004) and adult SSCs (Lassalle et al., 2004) it would be interesting to further investigate the cell lineage that links embryonic to adult SP germ cells.

In conclusion, we found that while SP phenotype is a common feature of PGCs in undifferentiated gonads and it becomes restricted in fetal testis to a cell population containing a small subset of prospermatogonia whose fate remains to be established.

\section{Materials and Methods}

\section{Animals}

CD-1 mice were obtained from our colony at the Department of Public Health and Cell Biology, University of Rome Tor Vergata. Transgenic mice (OG2) (Boiani et al., 2002; Yeom et al., 1996) expressing EGFP driven by the germ-cell specific promoter/enhancer region of the Oct4 gene (GOF-18/deltaPE) were kindly provided by K. John McLaughlin. Female CD-1 mice were mated with male OG2 mice to produce (CD-1 $x$ OG2) F1 hybrids. Animals were housed in a standard animal facility with free access to food and water, in accordance with the guidelines for animal care at the University of Rome Tor Vergata.

\section{Cell preparation}

Gonadal ridges (GRs) and testes were collected as previously described (De Felici, 1998) from embryos at 11.5, 13.5 and 18.5 day post coitus (dpc). The day on which a vaginal plug was detected was designated as $0.5 \mathrm{dpc}$. To obtain a single cell suspension, GRs (11.5 dpc) or 
testes (13.5 and $18.5 \mathrm{dpc}$ ) were collected in Hepes-MEM (GIBCO/BRL) with $10 \%$ BSA, dissected from mesonophroi, and incubated in trypsinEDTA solution for 5 min at room temperature, followed by gentle pipetting. Where indicated, PGCs were isolated from somatic cells by MiniMACS as previously described (Pesce and De Felici, 1995).

\section{Hoechst 33342 staining, flow cytometry analysis and cell sorting}

Hoechst 33342 staining and cytofluorimetric analysis was performed as described previously (Falciatori et al., 2004). Typically, cell suspensions (about 106 cells $/ \mathrm{ml}$ ) obtained from 50-60 $11.5 \mathrm{dpc}$ GRs, 35-40 13.5 dpc testes or 25-38 18.5dpc testes, were stained in MEM containing $5 \mu \mathrm{g} /$ $\mathrm{ml}$ Hoechst 33342 (Sigma, Milano) with or without $50 \mu \mathrm{M}$ verapamil (Sigma) at $37^{\circ} \mathrm{C}$ for $90 \mathrm{~min}$. After the incubation, cells were spun down, resuspended in PBS containing $1 \%$ fetal bovine serum and analyzed in a Vantage SE (Becton Dickinson) equipped with three lasers. Dead cells and debris were excluded from the plots by means of propidium iodide $(\mathrm{PI})$ staining $(2 \mu \mathrm{g} / \mathrm{ml})$. Hoechst dye was excited at $351 \mathrm{~nm}$, and the resulting fluorescence was split through a 640/LP filter and detected at two wavelengths using 424/44 (Hoechst blue) and 660/20 (Hoechst far red) filters. Cells labeled in the presence of verapamil were used in all experiments to set the SP gate. In experiments with OG2 mouse cells, cytofluorimetric analyses of wild-type testes were performed as control to set gates for GFP fluorescence. In some experiments, cells obtained from $11.5 \mathrm{dpc}$ GRs of OG2 mice were FACS analysed after staining with TG1 (SSEA-1) antibody (a kind gift from P. Donovan, University of Florida, USA), a specific marker of PGCs within the GRs (Solter et al., 1978) as reported in Cory et al. (2009).

Cell sorting was performed as previously described (Grisanti et al., 2009). Data were analyzed using Summit Software v. 4.3.1 (Cytomation). At least three experiments were performed for each testis developmental stage.

\section{Immunocytochemistry}

Immunostaining on sorted cells was performed as previously described (Pesce et al., 1995). Briefly, cells were attached to poly-I-lysinecoated slides and fixed in $4 \%$ paraformaldehyde at $4{ }^{\circ} \mathrm{C}$ for $10 \mathrm{~min}$. Staining was performed using goat anti-VASA (1:400; AbCam) antibody at room temperature for 1 hour. After washing, slides were incubated with donkey anti-goat Cy3-conjugated antibody (Molecular Probes) at room temperature for 1 hour. For negative control, the primary antibody was omitted from the staining procedure.

\section{RNA extraction and RT-PCR assay}

Total RNA was extracted from purified PGCs and somatic cells with RNeasy microkit (Qiagen) in accordance with the manufacturer's instructions. First-strand cDNA synthesis was performed as follows: $50 \mathrm{ng}$ of total RNA was reverse transcribed by $50 \mathrm{U}$ of Superscript ${ }^{\mathrm{TM}}$ II (Invitrogen) using $50 \mathrm{ng}$ of random hexamers, in the presence of $0.5 \mu \mathrm{M}$ deoxynucleotide triphosphates in a final volume of $20 \mu$ l. The reaction mixture was incubated for $1 \mathrm{~h}$ at $42^{\circ} \mathrm{C}$ and then heat denatured for $15 \mathrm{~min}$ at $75^{\circ} \mathrm{C}$. DNA contamination or PCR carryover controls were performed omitting reverse transcriptase during reverse transcription step. Four microliters of cDNA was amplified using the following PCR conditions: $94^{\circ} \mathrm{C}$ for $1 \mathrm{~min}$, $55^{\circ} \mathrm{C}$ for $1 \mathrm{~min}, 72^{\circ} \mathrm{C}$ for $1 \mathrm{~min}$ for 30 cycles. The following primers were used:

Abcg2 (Gene Bank accession: NM_011920)

forward 5'-AAATGGAGCACCTCAACCTG-3' reverse 5'-CCCATCACAACGTCATCTTG-3'

Abcb1a (Gene Bank accession NM_011076.2)

forward 5'-ACGGACAGGACATCAGAACC-3'

reverse 5'-CCTGACTCACCACACCAATG-3'

Abcb1b (Gene Bank accession NM_011075)

forward 5'-TTGGCACAACAACTCAT-3'

reverse 5'-GGCTTTCGCATAGTCAGGAG-3'

Abcc1 (Gene Bank accession NM_008576) forward 5'-CACATGTTGGGAAGCACATC-3' reverse 5'-GACCAGGATCCGTGTCTTGT-3'.

\section{Acknowledgements}

We are grateful to $K$. John McLaughlin for kindly providing OG2 transgenic mice. This work was supported by grants from MIUR Cofin and Ministry of Health targeted projects.

\section{References}

ANDERSON, R., FASSLER, R., GEORGES-LABOUESSE, E., HYNES, R. O. BADER, B. L., KREIDBERG, J. A., SCHAIBLE, K., HEASMAN, J. and WYLIE, C. (1999). Mouse primordial germ cells lacking beta1 integrins enter the germline but fail to migrate normally to the gonads. Development 126: 16551664.

BOIANI, M., ECKARDT, S., SCHOLER, H. R. and MCLAUGHLIN, K. J. (2002). Oct4 distribution and level in mouse clones: consequences for pluripotency. Genes Dev 16: 1209-1219.

BUNTING, K. D., ZHOU, S., LU, T. and SORRENTINO, B. P. (2000). Enforced Pglycoprotein pump function in murine bone marrow cells results in expansion of side population stem cells in vitro and repopulating cells in vivo. Blood 96: 902909.

CHALLEN, G. A. and LITTLE, M. H. (2006). A side order of stem cells: the SP phenotype. Stem Cells 24: 3-12.

DE FELICI, M. (1998). Isolation and culture of germ cells from the mouse embryo. In Cell biology: a laboratory handbook. (Ed.J.E. Celis). Academic Press, New York, pp. 73-85.

DE FELICI, M., FARINI, D. and DOLCI, S. (2009). In or out stemness: comparing growth factor signalling in mouse embryonic stem cells and primordial germ cells. Curr. Stem Cell Res Ther 4: 87-97.

DE FELICI, M. and MCLAREN, A. (1983). In vitro culture of mouse primordial germ cells. Exp. Cell Res. 144: 417-427.

DONOVAN, P. J. and DE MIGUEL, M. P. (2003). Turning germ cells into stem cells. Curr Opin Genet Dev. 13: 463-471.

FALCIATORI, I., BORSELLINO, G., HALIASSOS, N., BOITANI, C., CORALLINI, S., BATTISTINI, L., BERNARDI, G., STEFANINI, M. and VICINI,E. (2004). Identification and enrichment of spermatogonial stem cells displaying sidepopulation phenotype in immature mouse testis. FASEB J 18: 376-378.

GINSBURG, M., SNOW, M. H, AND MCLAREN, A. (1990). Primordial germ cells in the mouse embryo during gastrulation. Development 110: 521-528.

HILSCHER, B., HILSCHER, W., BULTHOFF-OHNOLZ, B., KRAMER, U., BIRKE, A., PELZER, H. AND GAUSS,G. (1974). Kinetics of gametogenesis. I. Comparative histological and autoradiographic studies of oocytes and transitional prospermatogonia during oogenesis and prespermatogenesis. Cell Tissue Res 154: 443-470.

LASSALLE, B., BASTOS, H., LOUIS, J.P., RIOU, L., TESTART, J., DUTRILLAUX B., FOUCHET, P. and ALLEMAND, I. (2004). 'Side Population' cells in adult mouse testis express Bcrp1 gene and are enriched in spermatogonia and germinal stem cells. Development 131: 479-487.

LAWSON, K.A. and HAGE, W.J. (1994). Clonal analysis of the origin of primordial germ cells in the mouse. In Germline Development. (Eds J. Marsh and J. Goode). Ciba Found Symp vol.182, pp. 68-84.

LO, K. C., LEI, Z., RAO, C., BECK, J., and LAMB, D. J. (2004). De novo testosterone production in luteinizing hormone receptor knockout mice after transplantation of leydig stem cells. Endocrinology 145: 4011-4015.

MCLAREN, A. (1995). Germ cells and germ cell sex. Philos. Trans $R$ Soc Lond $B$ Biol Sci 350: 229-233.

MCLEAN, D. J., FRIEL, P. J., JOHNSTON, D.S. and GRISWOLD, M.D. (2003) Characterization of spermatogonial stem cell maturation and differentiation in neonatal mice. Biol Reprod 69: 2085-2091.

OHBO, K., YOSHIDA, S., OHMURA, M., OHNEDA, O., OGAWA, T., TSUCHIYA H., KUWANA, T., KEHLER, J., ABE, K., SCHOLER, H.R. and SUDA, T. (2003). Identification and characterization of stem cells in prepubertal spermatogenesis in mice small star, filled. Dev Biol 258: 209-225.

OHINATA,Y., PAYER, B., O'CARROLL, D., ANCELIN, K., ONO, Y., SANO, M. 


\section{M.L. Scaldaferri et al.}

BARTON, S. C., OBUKHANYCH,T., NUSSENZWEIG, M., TARAKHOVSKY, A., SAITOU, M. and SURANI, M.A. (2005). Blimp1 is a critical determinant of the germ cell lineage in mice. Nature 436: 207-213.

OHMURA, M., NAKA, K., HOSHII,T., MURAGUCHI,T., SHUGO, H., TAMASE, A., UEMA, N., OOSHIO, T., ARAI, F., TAKUBO, K., NAGAMATSU, G., HAMAGUCHI, I., TAKAGI, M., ISHIHARA, M., SAKURADA, K., MIYAJI, H., SUDA,T. and HIRAO, A. (2008). Identification of stem cells during prepubertal spermatogenesis via monitoring of nucleostemin promoter activity. Stem Cells 26: 32373246.

PESCE, M. and DE FELICI, M. (1995). Purification of mouse primordial germ cells by MiniMACS magnetic separation system. Dev Biol 170: 722-725.

ROCHON, C., FROUIN, V., BORTOLI, S., GIRAUD-TRIBOULT, K., DUVERGER, V., VAIGOT, P., PETAT, C., FOUCHET, P., LASSALLE, B., ALIBERT, O., GIDROL, X. and PIETU, G. (2006). Comparison of gene expression pattern in SP cell populations from four tissues to define common «stemness functions». Exp Cell Res 312: 2074-2082.

SCHMAHL, J., EICHER, E. M., WASHBURN, L. L. and CAPEL, B. (2000). Sry induces cell proliferation in the mouse gonad. Development 127: 65-73.

SUSANTO, J., LIN,Y.H., CHEN,Y.N., SHEN,C.R., YAN,Y.T., TSAI, S.T., CHEN, C.H. and SHEN, C.N. (2008). Porphyrin homeostasis maintained by ABCG2 regulates self-renewal of embryonic stem cells. PLoS One 3: e4023.

UENO, H., TURNBULL, B. B. and WEISSMAN, I. L. (2009). Two-step oligoclonal development of male germ cells. Proc Natl Acad Sci USA 106: 175-180.
VIEYRA, D.S., ROSEN, A. and GOODELL, M.A. (2009). Identification and Characterization of Side Population Cells in Embryonic Stem Cell Cultures. Stem Cells Dev 18: 1155-1166.

WESTERN, P.S., MILES, C., VAN DEN BERGEN, J. A., BURTON, M. and SINCLAIR, A. H. (2008). Dynamic regulation of mitotic arrest in fetal male germ cells. Stem Cells 26: 339-347.

YEOM,Y. I., FUHRMANN, G., OVITT,C. E., BREHM, A., OHBO, K., GROSS, M., HUBNER, K. and SCHOLER, H. R. (1996). Germline regulatory element of Oct4 specific for the totipotent cycle of embryonal cells. Development 122: 881-894.

YOSHIMIZU,T., SUGIYAMA, N., DE FELICE, M., YEOM,Y.I., OHBO, K., MASUKO K., OBINATA, M., ABE, K., SCHOLER, H.R. and MATSUI,Y. (1999). Germlinespecific expression of the Oct-4/green fluorescent protein (GFP) transgene in mice. Dev Growth Differ 41: 675-684.

ZHOU, S., MORRIS, J. J., BARNES, Y., LAN, L., SCHUETZ, J. D. and SORRENTINO, B. P. (2002). Bcrp1 gene expression is required for normal numbers of side population stem cells in mice, and confers relative protection to mitoxantrone in hematopoietic cells in vivo. Proc Natl Acad Sci USA 99: 12339-12344.

ZHOU, S., SCHUETZ, J. D., BUNTING, K. D., COLAPIETRO, A. M., SAMPATH, J., MORRIS,J. J., LAGUTINA, I., GROSVELD, G.C., OSAWA, M., NAKAUCHI, H. and SORRENTINO, B. P. (2001). The ABC transporter Bcrp1/ABCG2 is expressed in a wide variety of stem cells and is a molecular determinant of the side-population phenotype. Nat Med 7: 1028-1034. 


\section{Further Related Reading, published previously in the Int. J. Dev. Biol.}

Analysis of SOX2 expression in developing human testis and germ cell neoplasia Si B. Sonne, Rebecca M. Perrett, John E. Nielsen, Melissa A. Baxter, David M. Kristensen, Henrik Leffers, Neil A. Hanley and Ewa RajpertDe-Meyts

Int. J. Dev. Biol. (2010) 54: 755-760

The allocation and differentiation of mouse primordial germ cells

T E Tsang, P L Khoo, R V Jamieson, S X Zhou, S L Ang, R Behringer and P P Tam

Int. J. Dev. Biol. (2001) 45: 549-555

Differentiation of mouse primordial germ cells into female or male germ cells

N Nakatsuji and S Chuma

Int. J. Dev. Biol. (2001) 45: 541-548

Regulation of primordial germ cell development in the mouse

M De Felici

Int. J. Dev. Biol. (2000) 44: 575-580

The meiotic specific synaptonemal complex protein SCP3 is expressed by female and male primordial germ cells of the mouse embryo

A D Di Carlo, G Travia and M De Felici

Int. J. Dev. Biol. (2000) 44: 241-244

Transplantation of testis germinal cells into mouse seminiferous tubules

T Ogawa, J M Aréchaga, M R Avarbock and R L Brinster

Int. J. Dev. Biol. (1997) 41: 111-122

5 yr ISI Impact Factor $(2009)=3.253$

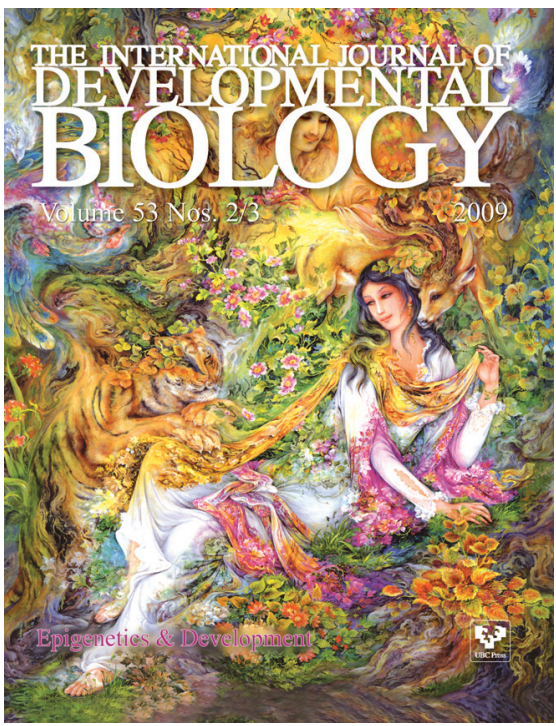

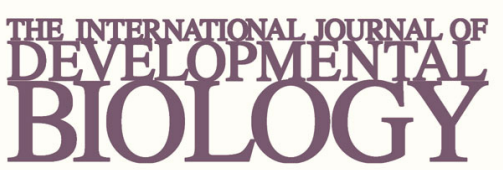

Volume 54 Nos. 6/7

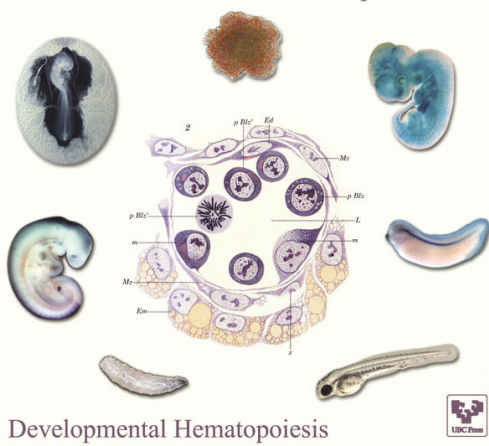

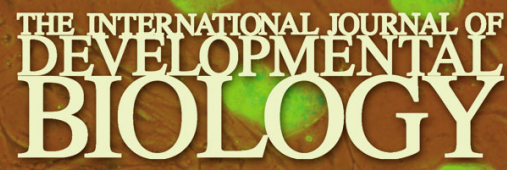

Volume 54 Nos. 11/12

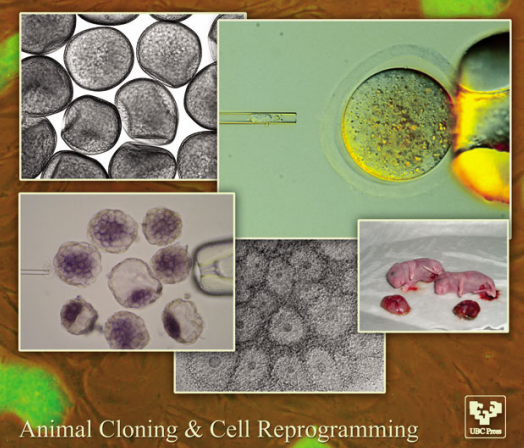

